\title{
"INTERAÇÃO E SILÊNCIO NA SALA DE AULA": O SILÊN CIO COMO VEICULADOR DE SENTIDO E INTERAÇÃO*
}

\author{
EdWiges M aria M orato**
}

\begin{abstract}
Pesquisadora: Andréa, vamos escrever. 0 que você quer comprar? Andréa: (não responde)

Pesquisadora: Vamos escrever café?

Andréa: (não responde)

Pesquisadora: 0 u você quer escrever arroz?

Andréa: (não responde)

Pesquisadora: 0 que você prefere, Andréa? H ein, hein, Andréa?
\end{abstract}

(Laplane, 2000, p.70-71)

As práticas interativas produzidas no âmbito escolar, sob os mais diferentes ângulos, têm sido objeto de estudo de vários domínios do saber, como a Pedagogia, a Lingüística, a Psicologia ou a Sociologia. Em cada domínio, a expectativa de entendimento de suas propriedades, características e implicações parece voltar-se à observação dos diferentes sentidos que constituem as interações, ou os que estas provocam, engendram, denunciam, revelam. Além disso, espera-se que a qualidade das interações tenha a ver, de alguma maneira, com os limites e os alcances da escola enquanto instituição, enquanto prática social.

Q ual o sentido das interações produzidas na sala de aula num contexto educacional marcado tanto pelo discurso da competência (interacional e comunicativa) quanto pelo da ineficiência da escola tradicional, tanto pelo discurso da mudança social quanto pelo da globalização, tanto pelo discurso logocêntrico quanto pelo do questio-

\footnotetext{
* LAPLAN E, Adriana Friszman de. Interação e silêncio na sala de aula. Ijuí: Editora U nijuí, 2000.

** Professora do Departamento de Lingüística do Instituto de Estudos da Linguagem (IEL/ U nicamp. E-mail: edwiges@iel.unicamp.br
} 
namento das estratégias autoritárias, centradas na visão idealizada que a sociedade faz de si mesma (da linguagem, da comunicação, da interação)? E is a discussão proposta pelo livro de Adriana Friszman de Laplane, Interação e silêncio na sala deaula, Iançado pela E ditora U nijuí no ano passado.

Recuperando o sentido da noção de silêncio na modernidade e o da noção de interação nos estudos desenvolvidos no campo da Lingüística e da Psicologia, a autora explora a relação entre ambos no contexto da sala de aula, apontando como atuam na construção (discursiva) das práticas sociais e da própria subjetividade. Em uma perspectiva de base etnográfica, ela analisa o silêncio em meio a práticas interativas que envolvem professores e alunos em uma sala de primeira série do ensino fundamental de uma escola pública de Campinas.

Como delimitar os fenômenos reunidos em torno dos termos interação e silêncio? 0 que primeiro se evoca nos trabalhos de tradição pluridisciplinar voltados para a análise da interação é a idéia de ação conjunta que coloca em jogo dois ou mais sujeitos, tanto conflituosa quanto cooperativa. Como bem nota Robert Vion, autor que dedicou um livro à análise das interações (1992), essa definição não marca nenhuma diferença entre trocas conversacionais, transações financeiras, jogos amorosos ou lutas de boxe. D e qualquer maneira, ela indica que toda empreitada ou ação do sujeito no mundo se inscreve num quadro cultural e submete-se às regras pragmáticas que são garantidas por gestão social. Tal constatação nos conduz ao postulado bakhtiniano, segundo o qual "toda conduta humana procede de interação".

Geraldi (1991) exprime bem a síntese das idéias de Bakhtin ao situar histórico-social mente o espaço no qual se dão as interações entre os sujeitos. Em suas palavras, estas

não se dão "metafisicamente", sem constrições [...] As sociedades organizam e controlam, numa rede de sistemas, as interações possíveis [...] As interações não se dão fora de um contexto social e histórico mais amplo; na verdade, elas se tornam possíveis enquanto acontecimentos singulares, no interior enos limites de uma determinada formação social, sofrendo as interferências, os controles e as seleç̃ões impostas por esta. T ambém não são, em relação a estas condições, inocentes. São produtivas e históricas, e como tais, acontecendo no interior e nos limites do social, constróem por sua vez limites novos. (0 p. cit., p. 6)

Professora e pesquisadora da área educacional, Laplane discute essa questão tendo por base a análise de interações tidas como ineficazes ou conflituosas entre crianças e adultos (alunos e professores, mais pre- 
cisamente) em uma situação escolar emblemática - a sala de aula. Encontramos nas interações anal isadas pela autora crianças que simplesmente não falam com adultos. Cumpre ressaltar que não temos aqui uma situação em que alunos se furtam a falar com seus professores, mas sim o de crianças ("crianças-problema") que, na escola, não falam com adultos: "A característica mais marcante dessas crianças é que, mesmo quando são solicitadas a participar, instadas a responder perguntas ou a realizar atividades escolares, elas persistem no silêncio" (p. 10).

$D$ o ruidoso ambiente de sala de aula, entre fal antes contumazes e silenciosos teimosos, a análise de L aplane destaca as ações e os movimentos de sentido produzidos pelos protagonistas dessa "arena de lutas" marcada pela consagração da concepção da linguagem qua comunicação (reflexo de uma espécie de capacidade intrínseca de que seríamos dotados, a "comunicabilidade") e pela injunção social e discursiva contra o silêncio, ambas praticadas em nossa tradição cultural.

N os episódios analisados, os adultos, na sala de aula, "esforçamse em convocar os alunos a falar, utilizando para isso diversas estratégias. A maioria das vezes, nos casos que analisamos, o resultado da convocação é negativa. Q uanto mais as crianças são chamadas a falar, mais o silêncio se instala" (op. cit., p. 109). Por que as estratégias dos adultos não são bem sucedidas? Segundo a autora, "em parte, porque quando os adultos convocam, não estão, simplesmente, chamando a criança a falar. As crianças são convocadas a falar como alunas, a engajar-se nas atividades escolares, a produzir, a obedecer. As estratégias dos adultos (a insistência, a repetição, a reformulação), por outra parte, parecem reforçar, justamente, o que há de mais fico neste tipo de interação: a assimetria, as relações de subordinação e de autoridade" (p. 109-110).

Entendendo o silêncio como um tipo particular de interação e como vei culador de sentidos, uma das tarefas a que a autora se lança em sua reflexão é precisamente extrair do termo sua polissemia e sua discursi vidade inarredáveis: silêncio, silenciamento, implícito, subentendido, exclusão, resistência, opressão. Torna-se necessário buscar uma formulação discursiva para o silêncio. Com isso, postula-se que o silêncio significa, que ele é significado, interpretado. 0 silêncio, então, não é ausência de interação, não é refúgio voluntário e idiossincrático em meio à batalha verbal e ao domínio da fala; não é falta ou excrescência se comparado à linguagem. Antes, se o silêncio faz parte da construção do sentido (da interação, da comunicação), é também ato de linguagem, ato da significação. Como afirma a autora, "onde há linguagem, há também silêncio" (p. 78). Se há continuidade e não ruptura entre 
linguagem e silêncio, o que poderíamos entender da recusa da posse da palavra e do turno de fala por parte de al unos que não falam com adultos em situação escolar? Eis que a aparente não-comunicação também faz parte da idéia de comunicação; a não-interação também faz parte da interação. 0 silêncio faz parte da linguagem.

$N$ esse ponto, outro conceito, o de interação, deve ser tomado em toda sua complexidade. A concepção dialógico-discursiva da interação, retomada de Bakhtin, parte das condições materiais (histórico-sociais, psico-afetivas, contextuais) de sua configuração. A noção de interação aqui não é reduzida a uma espécie de "curinga categorial" das ciências sociais enem é predicada como necessariamente positiva. Em apenas um de seus sentidos, a interação pode definir-se como ação de reciprocidade.

0 tipo de interação estudado por L aplane nos leva a admitir que entre suas propriedades constitutivas, isto é, de reciprocidade, influência e troca, somam-se a do silêncio, da contrariedade, da assimetria, da "ineficácia" e da iniqüidade interpessoal.

Assim problematizada, a questão ressalta quea relevância da interação enquanto categoria de análise reside não apenas no fato de que ela é capaz de colocar em relação dois sujeitos ou mais, mas porque há em seu interior uma dimensão discursiva que a caracteriza como uma qualidade propriamente humana, ideológica, social, histórica, afetiva.

Se a noção de interação (aplicada às relações entre linguagem e silêncio, às relações entre enunciadores, às relações entre a norma e 0 desejo, entre outros) for concebida intersubjetivamente, ela terá suas contingências marcadas pelo poder da linguagem, pelas relações de força que se instauram no interior de cada situação interativa, pelo funcionamento heurístico (e não apenas estrutural) de diversos processos de significação que a engendram. I sso mesmo quando a linguagem, de seu ponto de vista estrutural e organizacional, esteja aparentemente ausente, como no caso do silêncio persistente das crianças de que nos fala Laplane em seu livro. Com relação ao silêncio tenaz de uma das crianças, a mesma com cujo silêncio se abriu esta resenha, diz a autora:

0 silêncio deAndréa devol veaos "adultos-que-sabem" uma contra-imagem de si mesmos. Andréa étestemunha muda da impotência, da impossibilidade, do limite, talvez da própria incompetência dos adultos. 0 silêncio deAndréa evoca um silêncio que atravessa a fala dos adultos na busca de sentido. (P. 104)

A parentemente cético, esse arrazoado da autora encerra, sob a forma de uma reflexão ousada, um desafio para a formulação de teorias 
pedagógicas críticas e para as práticas de ensino transformadoras. 0 resto é silêncio.

Recebido para publicação em maio de 2001.

Referências bibliográficas

BAKH TIN , M . M arxismo eFilosofia da Linguagem. São Paulo: H ucitec, 1981.

GERALDI, J.W. Portos de passagem. São Paulo: M artins Fontes, 1991.

VION, R. La communication verbale - Analyse des interactions. Paris: H achette, 1992. 